\title{
AN EVALUATION OF THE WIND ENERGY IN THE NORTH SEA COAST
}

\author{
Article DOI : https://doi.org/10.35219/mtd.2019.1.02 \\ Alexandra DIACONITA, Florin ONEA, Eugen RUSU \\ University "Dunarea de Jos” of Galati, Department of Mechanical Engineering, Romania \\ E-mail: diaconita.ionelia@ugal.ro
}

\begin{abstract}
For the present work, 10 offshore wind farms from the North Sea were selected. Here there are a high number of wind farms (41 farms) due to the high capacity of the wind resources that this sea offers. For this study, wind speed data for a period of about 20 years were used, these data were provided by the The European Centre for Medium-Range Weather Forecasts. After data processing, wind power values were obtained in the range of $538 \ldots 879 \mathrm{~W} / \mathrm{m}^{2}$. Considering the characteristics of the turbines that were mounted on the locations of each wind farm, the values for annual electricity production were obtained (for a single wind turbine), this parameter having values between 3974-26130 MWh. The lower value being associated with the oldest eoline farm Blyth Offshore, this farm will be removed or improved in the near future.
\end{abstract}

Keywords: North Sea, wind resources, re-analysis data, offshore turbine, power curve

\section{INTRODUCTION}

Renewable energies are those energies that come from natural resources that are not depleted and that can be used permanently. Its environmental impact is zero in emission of greenhouse gases, such as $\mathrm{CO}_{2}$. Wind energy is one of the renewable energies with the most installed capacity in the world and it is the one that has experienced faster growth. The development of technology associated with wind energy has allowed for the manufacture of wind generators to evolve [1].

Wind energy currently supplies more than $3 \%$ of the world's electricity consumption and it is expected that, by 2020 , it will surpass $5 \%$. In longer term, the International Energy Agency forecasts that wind energy can cover $9 \%$ of global electricity demand and more than $20 \%$ in Europe [2].

The total capacity of wind energy has reached the value of $600 \mathrm{GW}$. About 53.9 MW were added in 2018. This year was the second year in a row when there was an increase in wind power capacity. Among the countries that contributed to this growth the authors can mention: China (25.9 Gigawatt added), USA (7.9 Gigawatt added), Germany (3.4 Gigawatt added), India (2.1 Gigawatt added), United Kingdom (2.9 Gigawatt added), Brazil (1.7 Gigawatt added) and France (1.5 Gigawatt added) [4], [5].
In Europe, in 2018, wind power capacity increased with $11.7 \mathrm{GW}$, Germany being the leader, covering about $29 \%$ of the capacity at total of just 3.4 $\mathrm{GW}$, with $2.4 \mathrm{GW}$ of this onshore and the rest on offshore.

\section{MATERIALS AND METHODS}

\subsection{Target area}

The target area of this study is the North Sea. The North Sea has the best offshore wind resources, wind speeds are high, relatively constant and the waters are shallow [6]. Ten wind farms were selected, which are shown in Fig. 1. From those wind farms, it is worthy to mention the Gemini BuitenGaats \& ZeeEnergie Farm, which is one of the largest project in the world.

\subsection{ERA-Interim database}

The European Centre for Medium-Range Weather Forecasts is a research institute and a 24/7 operational service. One of their projects is the ERAInterim database, which is the third generation of reanalysis, an improvement of the project ERA-40 [7]. ERA-Interim is a global atmospheric reanalysis from 1979, which is produced with a sequential data assimilation scheme, using a 12-hour analysis window. 


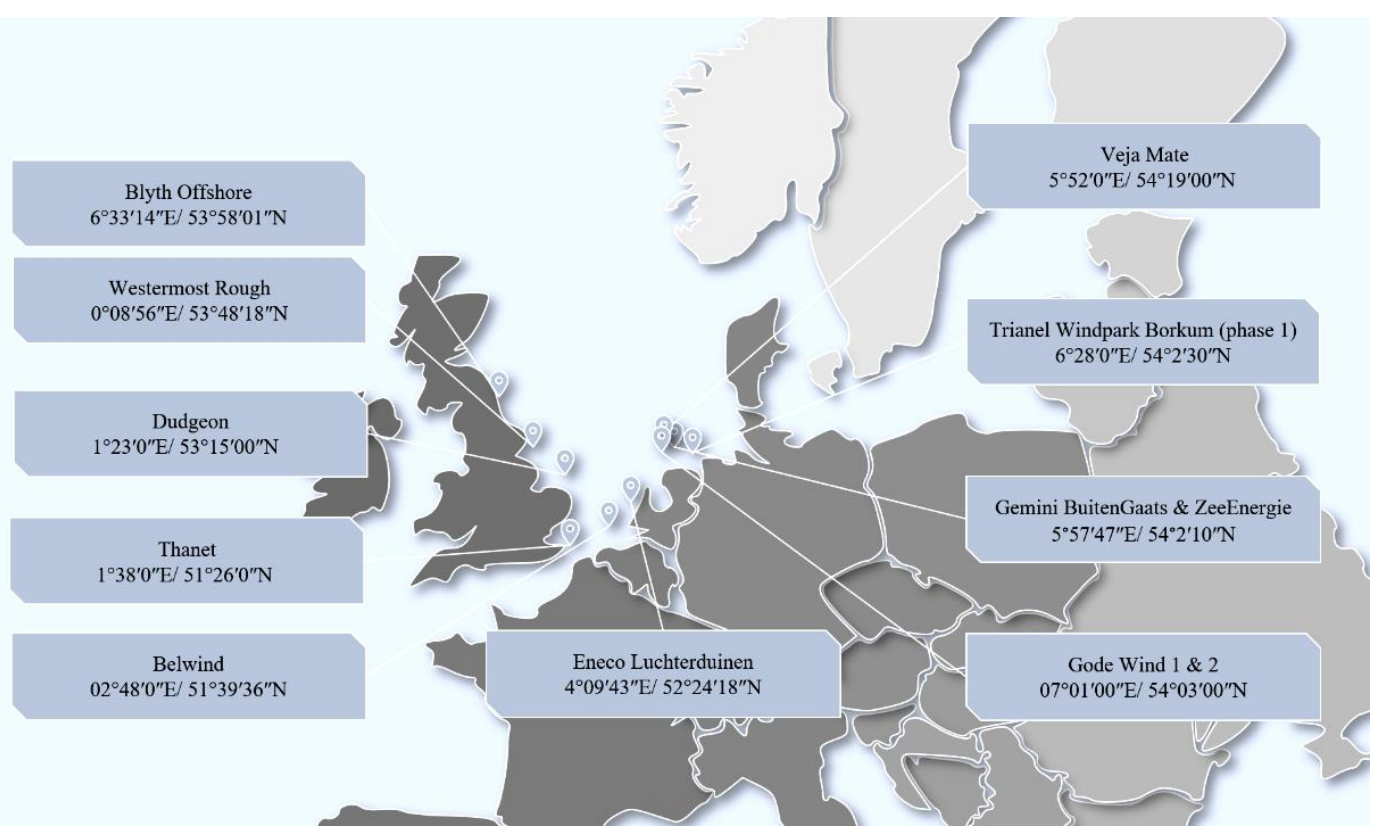

Fig. 1. List of wind farms used for this study

Table 1. Main characteristics of the 10 offshore wind farms operating in North Sea

\begin{tabular}{|c|c|c|c|c|c|c|c|}
\hline Farm & Wind farm & $\begin{array}{c}\text { Cap } \\
(\mathrm{MW})\end{array}$ & Turbines & Longitude & Latitude & $\begin{array}{l}\text { Depth } \\
\text { (m) }\end{array}$ & $\begin{array}{c}\text { Distance to } \\
\text { shore } \\
(\mathrm{km})\end{array}$ \\
\hline 1 & Blyth Offshore & 4 & $\begin{array}{c}2 \times \text { Vestas V66- } \\
2 \mathrm{MW}\end{array}$ & $6^{\circ} 33^{\prime} 14^{\prime \prime} \mathrm{E}$ & $53^{\circ} 58^{\prime} 01^{\prime \prime} \mathrm{N}$ & $23-29$ & 55 \\
\hline 2 & $\begin{array}{c}\text { Gemini } \\
\text { BuitenGaats \& } \\
\text { ZeeEnergie }\end{array}$ & 600 & $\begin{array}{l}150 \times \text { Siemens } \\
\text { SWT-4.0-130 }\end{array}$ & $5^{\circ} 57^{\prime} 47^{\prime \prime} \mathrm{E}$ & $54^{\circ} 2^{\prime} 10^{\prime \prime} \mathrm{N}$ & 30 & 55 \\
\hline 3 & Belwind & 165 & $\begin{array}{l}55 \times \text { Vestas } \\
\text { V90-3.0MW }\end{array}$ & $02^{\circ} 48^{\prime} 0^{\prime \prime} \mathrm{E}$ & $51^{\circ} 39^{\prime} 36^{\prime \prime} \mathrm{N}$ & 25 & 46 \\
\hline 4 & Veja Mate & 402 & $\begin{array}{l}67 \times \text { Siemens } \\
\text { SWT-6.0-154 }\end{array}$ & $5^{\circ} 52^{\prime} 0^{\prime \prime} \mathrm{E}$ & $54^{\circ} 19^{\prime} 00^{\prime \prime} \mathrm{N}$ & 41 & 95 \\
\hline 5 & Westermost Rough & 210 & $\begin{array}{l}35 \times \text { Siemens } \\
\text { SWT-6.0-154 }\end{array}$ & $0^{\circ} 08^{\prime} 56^{\prime \prime} \mathrm{E}$ & $53^{\circ} 48^{\prime} 18^{\prime \prime} \mathrm{N}$ & $10-25$ & 8 \\
\hline 6 & $\begin{array}{l}\text { Trianel Windpark } \\
\text { Borkum (phase 1) }\end{array}$ & 200 & $\begin{array}{l}40 \times \text { Areva } \\
\text { M5000-116 }\end{array}$ & $6^{\circ} 28^{\prime} 0^{\prime \prime} \mathrm{E}$ & $54^{\circ} 2^{\prime} 30^{\prime \prime} \mathrm{N}$ & $28-33$ & 45 \\
\hline 7 & Thanet & 300 & $\begin{array}{l}100 \times \text { Vestas } \\
\text { V90-3.0MW }\end{array}$ & $1^{\circ} 38^{\prime} 0^{\prime \prime} \mathrm{E}$ & $51^{\circ} 26^{\prime} 0^{\prime \prime} \mathrm{N}$ & $20-25$ & 11 \\
\hline 8 & Gode Wind $1 \& 2$ & 504 & $\begin{array}{l}97 \times \text { Siemens } \\
\text { SWT-6.0-154 }\end{array}$ & $07^{\circ} 01^{\prime} 00^{\prime \prime} \mathrm{E}$ & $54^{\circ} 03^{\prime} 00^{\prime \prime} \mathrm{N}$ & 30 & 42 \\
\hline 9 & Eneco Luchterduinen & 129 & $\begin{array}{l}43 \times \text { Vestas } \\
\text { V112-3MW }\end{array}$ & $4^{\circ} 09^{\prime} 43^{\prime \prime} \mathrm{E}$ & $52^{\circ} 24^{\prime} 18^{\prime \prime} \mathrm{N}$ & $18-24$ & 24 \\
\hline 10 & Dudgeon & 402 & $\begin{array}{l}67 \times \text { Siemens } \\
\text { SWT-6.0-154 }\end{array}$ & $1^{\circ} 23^{\prime} 0^{\prime \prime} \mathrm{E}$ & $53^{\circ} 15^{\prime} 00^{\prime \prime} \mathrm{N}$ & $18-25$ & 32 \\
\hline
\end{tabular}

For each cycle, the parameters of the global atmosphere: surface pressure, temperature, humidity, wind, ozone are computed, followed by separate analyses of near-surface parameters ( $2 \mathrm{~m}$ temperature and $2 \mathrm{~m}$ humidity), ocean waves, soil moisture and temperature, snow. The data set has a spatial resolution of approximately $80 \mathrm{~km}$ on 60 vertical layers from the surface up to $0.1 \mathrm{hPa}$ [5].

Approximately 20 years of wind data were considered for this work, covering the period from
01.01.1999 to 31.08.2018. For this interval, the wind and wave data were processed, given a spatial resolution of $0.75 \times 0.75$ and a temporal resolution of 6 hours, 4 values per day, respectively.

\subsection{Wind turbines}

From Table 1, one may observe that those 10 wind farms use 6 types of turbines. The range of rated power that is covered by the 6 turbines starts at $2000 \mathrm{~kW}$ and reaches the maximum value of 6000 
$\mathrm{kW}$, these characteristics being presented in Table 2 . The hub hight for all wind turbine is considered to be $80 \mathrm{~m}$.

Figure 2 shows the power curves associated with the 6 types of turbines that were considered for this study.

ERA-Interim database deliver the wind speed values at the height of 10 meters above the sea level. To reach the height of $80 \mathrm{~m}$, there is considered a logarithmic law, having the following form [8]:

$$
U_{z}=U_{z \text { ref }} \frac{\ln \left(z / z_{0}\right)}{\ln \left(z_{\text {ref }} / z_{0}\right)}
$$

where $U_{z}$ represents the wind speed at a height $\mathrm{z}$ (in this case, $z$ was considered to be $80 \mathrm{~m}$ ), $U_{z \text { ref }}$ is the known wind speed at the height $z_{\text {ref }}$ (in this case, 10 $\mathrm{m}), z_{0}$ represents the roughness length, which was considered to be $0.0002 \mathrm{~m}$. [6]

The wind power density has the following formula $\left(P_{\text {wind }}\right.$ in $\left.\mathrm{W} / \mathrm{m}^{2}\right)[7]$ :

$$
P_{\text {wind }}=\frac{1}{2} \rho_{\text {air }} U_{z}^{2}
$$

where $U_{z}$ represents the wind speed at a height $\mathrm{z}$ (in this case $\mathrm{z}$ was considered to be $80 \mathrm{~m}$ ), $\rho_{\text {air }}$ is the air density (having the value $1.225 \mathrm{~kg} / \mathrm{m}^{3}$ ).
The Annual Electricity Production (AEP, in $\mathrm{MWh}$ ) of a wind turbine can be calculated using the formula [9]:

$$
A E P=T \times \int_{\text {cut }- \text { in }}^{\text {cut-out }} f(u) P(u) d u
$$

where $T$ represent the average hours per year, $f(u)$ represent the Weibull probability density function, $P(u)$ is the turbine power curve, the cut-in represents the speed at which the turbine starts to work (in this case, the values are between $3.5 \mathrm{~m} / \mathrm{s}-5$ $\mathrm{m} / \mathrm{s}$ ), as the wind speed increases above the wind speed, where the rated power value is reached, this could lead to turbine failure, to prevent this a breaking system is used, this is called cut-out (usually, it is around $25 \mathrm{~m} / \mathrm{s}$ ).

The capacity factor, $C_{f}$, can be obtained as [2]:

$$
C_{f}=\frac{A E P}{P_{R}} \times 100
$$

where $P_{R}$ represents the rated power of the wind turbine.

The wind is a source of energy, whose fundamental characteristic is irregularity. Wind variation is characterized by two points of view, temporal variations and spatial variations, being vital in selecting the location of a wind farm.

Table 2. Tehnical specification of the wind turbines

\begin{tabular}{|c|c|c|}
\hline Type of turbine & $\begin{array}{c}\text { Rated power } \\
(\mathrm{kW})\end{array}$ & $\begin{array}{c}\text { Rotor diameter } \\
(\mathrm{m})\end{array}$ \\
\hline Siemens SWT-4.0-130 & 4000 & 130 \\
\hline Vestas V90-3.0MW & 3000 & 130 \\
\hline Vestas V66-2.0MW & 2000 & 66 \\
\hline Siemens SWT-6.0-154 & 6000 & 154 \\
\hline Areva M5000-116 & 5000 & 116 \\
\hline Vestas V112-3.0MW & 3000 & 112 \\
\hline
\end{tabular}
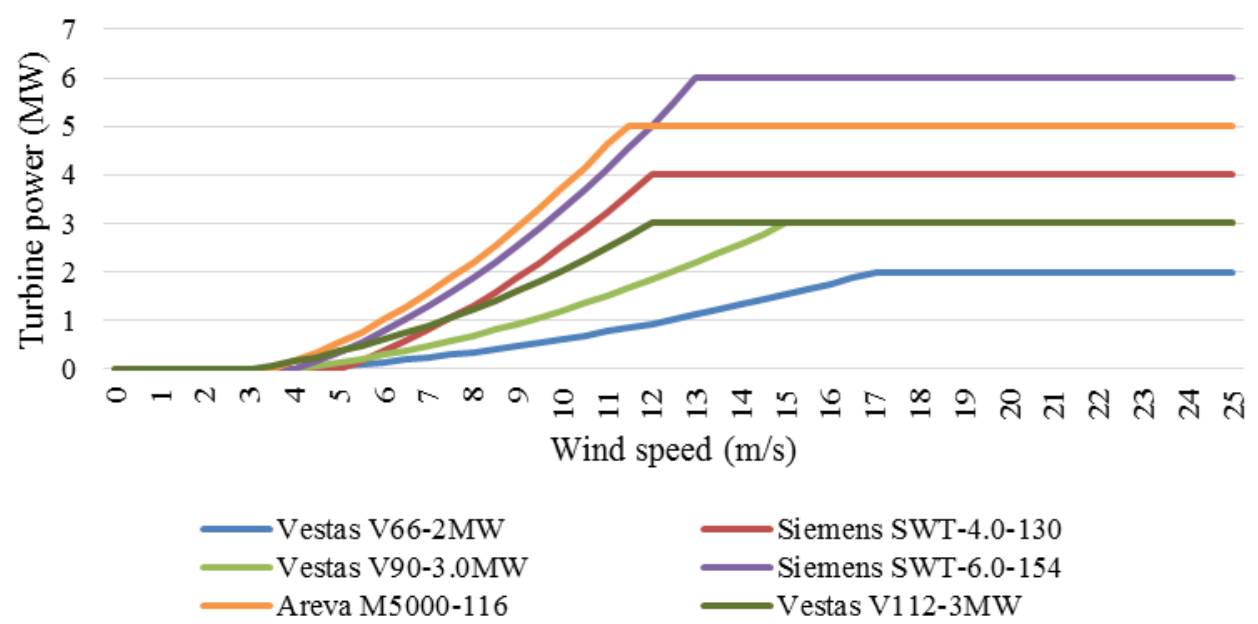

Fig. 2. Power curves of the considered turbines 
Usually, the wind has a relatively homogeneous behaviour within a month. Most of the wind systems are designed using a monthly basis. The seasonal variability of the wind has the same behavoir.

To evaluate those two, the authors are going to use the following equations [9].

$$
\begin{aligned}
& \text { Monthly }=\frac{P_{\text {Mwind }_{\max }}-P_{\text {Mwind }_{\text {min }}}}{P_{\text {Mwind }_{\text {average }}}} \\
& \text { Seasonal }=\frac{P_{\text {Swind }_{\max }} P_{\text {Swind }_{\text {min }}}}{P_{\text {Swind }_{\text {average }}}}
\end{aligned}
$$

where $P_{\text {Mwind }_{\max }}, P_{\text {Mwind }_{\min }}$ represent the maximum and minimum value from all months, respectively; $P_{\text {Swind }_{\max }}, \quad P_{\text {Swind }_{\min }}$ represent the maximum and

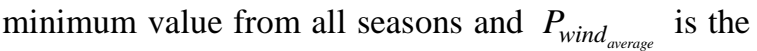
average value of the entire dataset.

\section{RESULTS AND DISCUSSION}

In Figure 3, one may see that monthly variations are higher than seasonal variations. It is also noted that monthly variations for all wind farms have close values and below 0.5 , the highest value being found to the site F1 and the lowest one to the site F8. For seasonal variation, the maximum value corresponds to the wind farm F10 and the lowest one to the wind farm F6.

During the year, the wind speed is changing, due to the seasonal regime of the general circulation of the atmosphere, the maximum values are usually found in winter. By looking at Figure 4, one may see that the maxim mean values of the wind speed are found on winter, also one can see that the lowest values are found in summer.

By looking at Figure 5, one may notice the mean value for the wind speed $\left(U_{90}\right)$, which is represented in the figure with the blue line, the peak value of 17.24 corresponding to the wind farm F4. The difference between the mean value and the 95th percentile is considerable.

Table 5 illustrates the values obtained for wind power at $U_{90}$. The table shows that the highest mean wind power values are found on wind farms F4, F6 and F2.

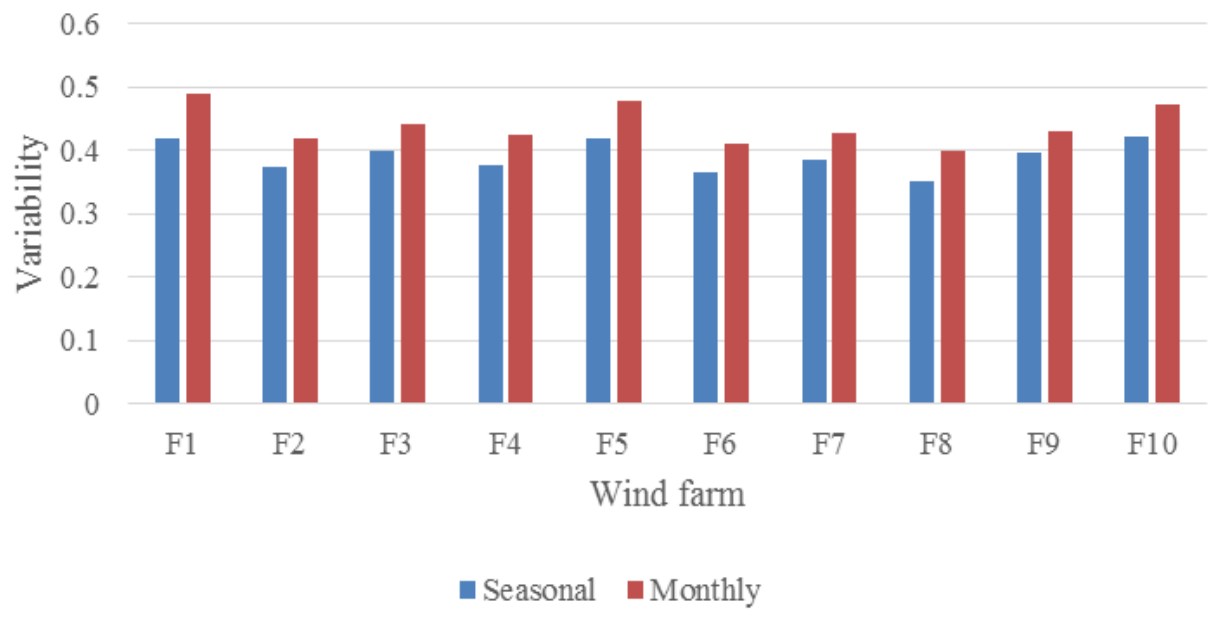

Fig. 3. Seasonal and monthly variability of the wind for the time interval from 1999 to 2018

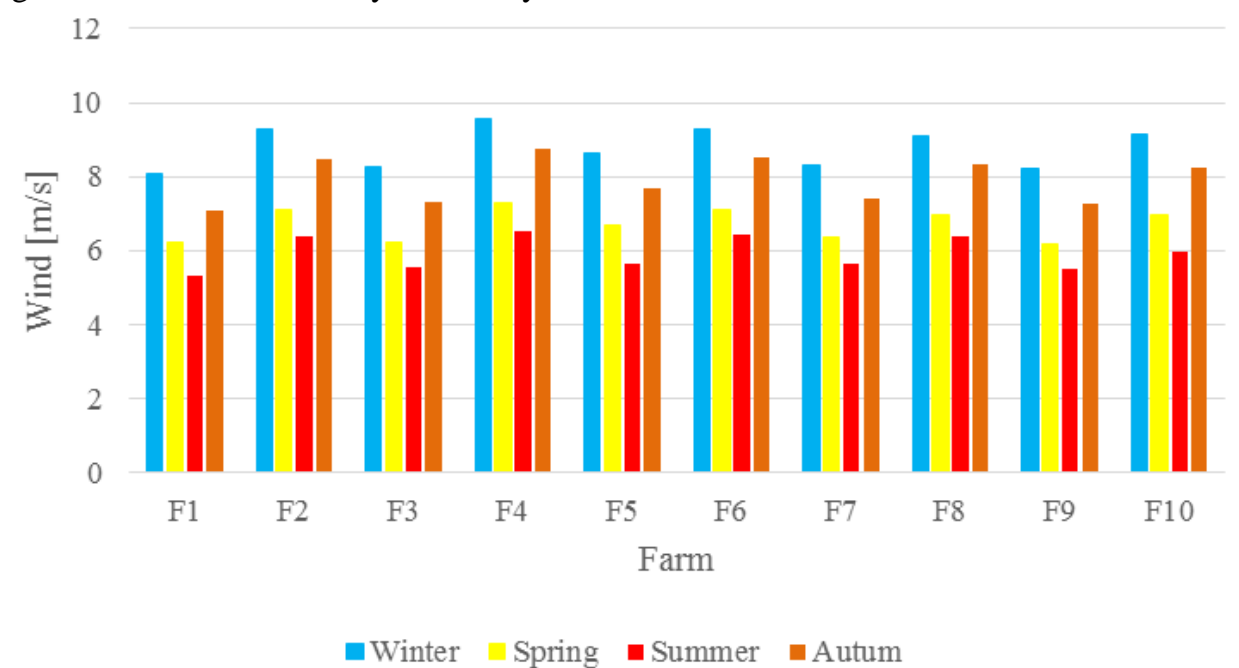

Fig. 4. Seasonal distribution of the wind speed (average values) for the time interval 1999-2018 


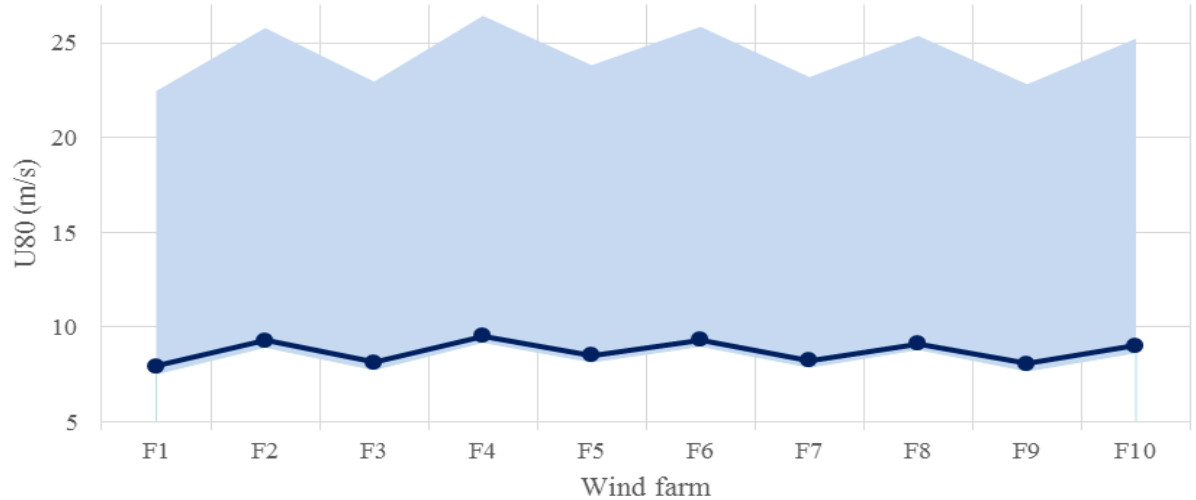

Fig. 5. Wind speed ( $U_{90}$ ) analysis of the historical data. The blue line represent the means, while the blue-gray shading indicates the range 50th-95th percentiles

Table 3. Wind characteristics at $80 \mathrm{~m}$, computed for 20 years period $1999-2018$

\begin{tabular}{|c|c|c|c|c|c|c|c|c|c|c|}
\hline & F1 & F2 & F3 & F4 & F5 & F6 & F7 & F8 & F9 & F10 \\
\hline Mean $\left(\mathrm{W} / \mathrm{m}^{2}\right)$ & 538 & 814 & 574 & 879 & 635 & 822 & 593 & 777 & 562 & 752 \\
\hline Max $\left(\mathrm{W} / \mathrm{m}^{2}\right)$ & 8723 & 14884 & 14478 & 16067 & 9721 & 14226 & 14342 & 14423 & 13318 & 11901 \\
\hline Std $\left(\mathrm{W} / \mathrm{m}^{2}\right)$ & 748 & 1058 & 790 & 1137 & 828 & 1064 & 810 & 1011 & 786 & 977 \\
\hline Skew $\left(\mathrm{W} / \mathrm{m}^{2}\right)$ & 2.945 & 2.939 & 3.057 & 2.969 & 2.640 & 2.923 & 3.010 & 2.973 & 3.176 & 2.647 \\
\hline 50th $\left(\mathrm{W} / \mathrm{m}^{2}\right)$ & 261 & 437 & 285 & 476 & 333 & 445 & 300 & 421 & 277 & 396 \\
\hline 95th $\left(\mathrm{W} / \mathrm{m}^{2}\right)$ & 2033 & 2920 & 2147 & 3127 & 2345 & 2928 & 2192 & 2771 & 2117 & 2780 \\
\hline
\end{tabular}

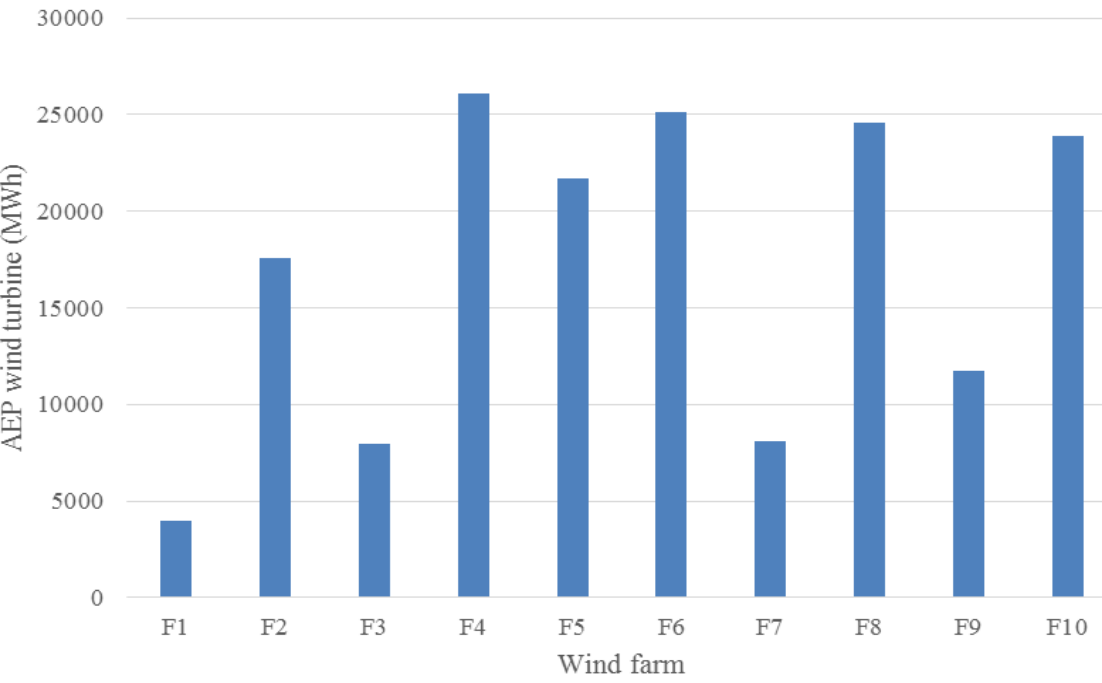

Fig. 6. Annual Energy Production (MWh) for one turbine on its location

Figure 6 illustrates the annual energy production for the turbines mentioned in Table 2. By looking at the figure, one may notice that the wind farm F4 has the greatest power expected for annual electricity production, for this wind farm, a Siemens SWT-6.0154 type of turbine was associated. The results outlined in this figure show that the wind farms F10 and F8 also have high values and for them the same type of turbine was used.

The lowest value is found at the Blyth Offshore F1 wind farm, which is also the oldest wind farm in the North Sea. For this wind farm, a Vestas V662MW turbine model was used.
Regarding the capacity factor, one may see from Fig. 7 that the highest value is found on the wind farm Trianel Windpark Borkum (phase 1) - F4, using a model of the turbine Areva M5000-116, but from the previous figure, it can be seen that this farm also had the second value obtained from the calculation of AEP.

The following high values for the capacity factor are found on wind farms using the Siemens SWT6.0-154 turbine model (F6, F8 and F10).

The lowest value was also obtained in this case for the Blyth Offshore - F1 wind farm. 


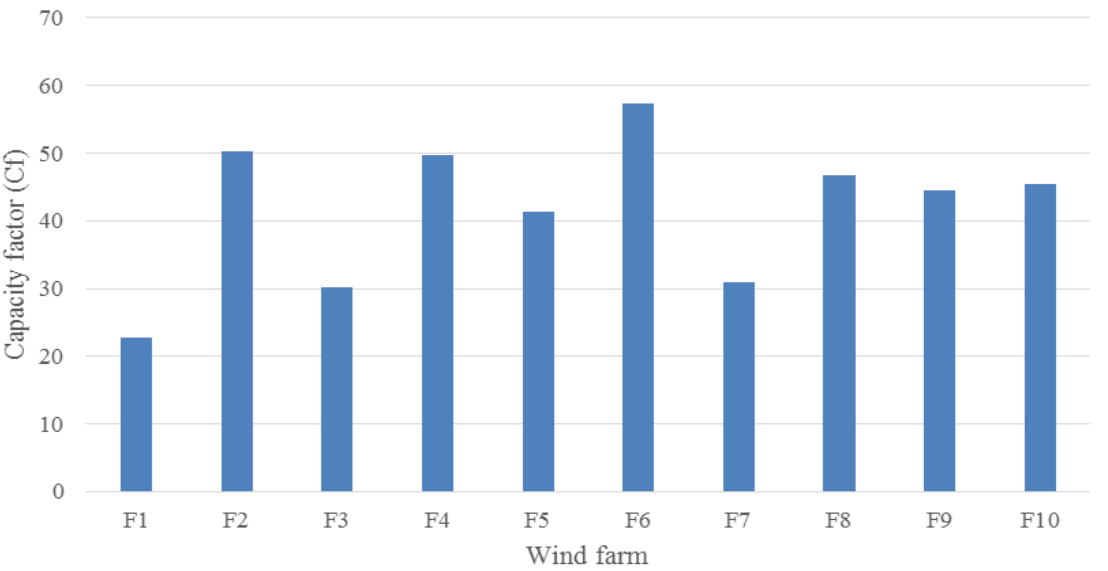

Fig. 7. The capacity factor of the wind turbines based on the wind data from the time interval 1999-2018

\section{CONCLUSIONS}

For this research work, a wind analysis was conducted for wind farms located in the North Sea. The distance from these wind farms to shore is about 8-55 km, they operate at depths of 10-22 m. This study focuses on data over a period of about 20 years 1999-2018. These results provide a picture of the wind industry at sea, from the available wind resources.

From these results, high wind speed values for F2, F4 (highest) and F6 were observed, which lead to high wind power values. For wind farm Veja Mate (F4), a mean wind speed value of $9.54 \mathrm{~m} / \mathrm{s}$ was obtained, corresponding to a mean wind power value of $879 \mathrm{~W} / \mathrm{m}^{2}$.

The assessment of the capacity factor indicates the reliability of the wind. The high values of this parameter are also obtained in this case for the points mentioned above. The highest value of 0.574 is found on the F6 wind farm.

By comparing the results obtained for the wind farms in the Baltic Sea, analyzed in the paper "Wind energy assessments in the Baltic Sea, past and future projections", one may see that the mean wind power obtained for the wind farms in the North Sea is close to those in the Baltic Sea, the second having slightly higher values (the highest value of wind power in the northern sea is 879 , the Baltic Sea having a value of 1008 [10].

\section{ACKNOLEDGMENT}

This work was carried out in the framework of the research project REMARC, supported by the Romanian Executive Agency for Higher Education, Research, Development, and Innovation Funding UEFISCDI, grant PN-III-P4-IDPCE-2016-0017.

\section{REFERENCES}

[1] Energia eolica nociones basicas, May 2017, Available: https://twenergy.com/guiaseficiencia-energetica/energia-eolica-nocionesbasicas [accessed May 2019].
[2] Barber S., Annual energy production Part 1 making sense of nameplate capacity, capacity factor, load factor and more, 26 June 2017 , https://www.windspire.ch/blog/2017/6/22/aeppart-1-capacity-and-more. [accessed May 2019].

[3] Energía eólica, Accino, May 2019 https://www.acciona.com/es/energiasrenovables/energia-eolica/ [accessed April 2019].

[4] Wind power capacity worldwide reaches 600 GW, 53,9 GW added in 2018, World Wind Energy Association, 25 February 2019, https://wwindea.org/blog/2019/02/25/windpower-capacity-worldwide-reaches-600-gw539-gw-added-in-2018/ [accessed May 2019].

[5] Haimber D. P., Dee S. M., Uppala A. J., Simmons P., Berrisford P. Poli S. Kobayashi U. Andrae M. A., Balmaseda G., Balsamo P. Bauer P. Bechtold A. C. M., Beljaars L., van de Berg J., Bidlot N., Bormann C., Delsol R., Dragani M., Fuentes A. J., Geer L., The ERA-Interim reanalysis: configuration and performance of the data assimilation system, 28 April 211, https://rmets.onlinelibrary.wiley.com/doi/full/10 .1002/qj.828 [accessed May 2019].

[6] North See, https://northsearegion.eu/northsee/eenergy/offshore-renewable-energy-industryoutlook-until-2030/. [accessed April 2019].

[7] About us: ECMWF, ECMWF, https://www.ecmwf.int/en/about [accessed April 2019].

[8] Rusu E., Soares Guedes C., Coastal impact induced by a Pelamis wave farm operating in the Portuguese nearshore, vols. Renew, Energy 58, pp. p. 34-49, 2013.

[9] Rusu E., Onea F., An assessment of the wind and wave power potential in the island environment, Energy, 175, pp. 830-84, 2019.

[10] Rusu E., 2014, Wind energy assessments in the Baltic Sea, past and future projections, Meteorological Applications, vol 21(2):316329. 